\title{
A Critical Component of Improving Education in Less-Developed Countries: Assessment for Learning
}

\author{
Daniel Light, Elizabeth Pierson \\ Center for Children and Technology, Education Development Center, Inc.
}

\begin{abstract}
Global policymakers are increasingly promoting the improvement of standardized examinations in developing countries, but the role of teacher-made classroom-based assessments is often ignored. Our research experience with the Intel ${ }^{\circledR}$ Teach professional development programs and other programs suggests that such approaches have great potential to provide students and teachers with feedback to guide and deepen learning. In this paper, we review the existing literature on assessment for learning in developing countries and propose that policy makers consider supporting research and development in five strategies: rubrics, performancebased assessments, portfolios, student selfassessment, and peer-assessment.
\end{abstract}

\section{Introduction}

This paper is a call to action to researchers and policy makers interested in improving education across the developing world. There is an increasingly prominent focus on improved assessment of student learning in the global movement for education reform, yet most of the focus is on improving national examinations and international benchmark tests that measure what students have learned. There is very little discussion about other assessment strategies that are known to have powerful impact on improving how students learn. Many nations and regional alliances have created improved standardized examinations [l] and there are valuable international collaborations such as Assessment \& Teaching of 21st Century Skills (ATC21S) that are developing assessment tasks to measure many more complex intellectual skills and abilities needed for the 21st century. However, these large-scale standardized examinations are not the only type of assessment that ministries of education should be thinking about. There is an important role for a different type of assessment that is created by teachers and is embedded into the daily practice of teaching and learning that is often called assessment for learning. This paper seeks to highlight the potential impact of assessment for learning in global education and to urge the research community, international organizations, and national ministries in developing countries to consider how these strategies may play a role in education reform efforts. We briefly review the research about assessment for learning, outline five key assessment approaches, and make suggestions for implementation. Both the research and our 15 years of experience observing classrooms suggest that these practices are viable strategies in developing country contexts.

\section{Assessment for learning}

Teachers always have assessed student knowledge with strategies such as recall tests or by asking content questions during a lecture, but researchers and practitioners are beginning to understand that other types of assessments can play an important role in supporting learning [2-4] and in transforming teaching practice. Assessment for learning, the term we will use, is the idea that classroom assessments should support ongoing teaching and learning [5, 6]; should be administered frequently; should be embedded into the learning process [7]; and can be effectively developed by classroom teachers $[2,4]$. Researcers have found that assessment for learning is one of the most powerful interventions available to improve student outcomes. In fact, in order to change daily teaching practices, teachers should start by updating their arsenal of assessment strategies [8]. In a seminal review of the literature on how people learn, the US National Research Council asserts, "appropriately designed assessments can help teachers realize the need to rethink their teaching practices" [9].

Despite the potential for assessment for learning practices to improve teaching and learning, there is little focus on promoting their use in developing countries. Assessment for learning strategies are becoming increasingly common in the richer countries of Europe, North America, and Australasia [5, 10-12], but the research we have found in developing countries suggests that these practices are barely used, if at all, and in many countries they are not even part of the conversation. 


\subsection{Assessment for learning in less-developed countries}

To assess the extent of current efforts to support these strategies in developing countries, we conducted a brief literature scan for published research in English, Spanish, French, and Portuguese about assessment for learning strategies in countries in SubSaharan Africa, Latin America, East Asia, South Asia, and Southeast Asia. We limited our search to five common strategies: rubrics, performance-based assessment, portfolios, self-assessment, and peerassessment. The policy research literature suggests that many ministries are thinking about the topic, but there is still little research around these practices in developing countries and few concerted efforts to promote their use [13-15]. Much of the effort on assessment is focused on improving national examinations [16]. In East Asia and Southeast Asia, most countries have well-established examination systems in place whose high-stakes social functions, such as gaining admission to university, make it hard to move away from these traditional approaches [17]. Additionally, the fact that countries such as Singapore, Korea, and Japan consistently top the lists on international examinations such as PISA or TIMMS adds validity to the idea that examinations promote quality [18]. Many of the Spanish- and Portuguesespeaking countries in South America have developed new standardized assessments of student learning at the national levels and also new regional assessments $[19,20]$. But the limited amount of research on classroom practice finds that most teachers in less developed countries still use traditional assessment approaches [15, 21-27].

\subsection{Potential impacts of teacher-made classroom assessments}

Over the past ten years, through our work as a global evaluation partner for the Intel ${ }^{\circledR}$ Teach teacher professional development programs ${ }^{1}$, our observations suggest that many classroom assessment strategies can work within the contextual challenges that teachers in developing countries often face-large class size, short lesson periods, and limited resources. These approaches have a proven impact in a variety of wealthy countries and, we assert, can be similarly effective across a range of developing-country contexts. There are four main dimensions of teachermade classroom assessments that the literature

\footnotetext{
1 The portfolio of programs we have evaluated include The Essentials Course, Getting Started, Teaching Thinking with Technology, and the Leadership Forums.
}

suggests can effectively push teaching and learning into the 21 st century.

1. Provide insight on student learning so teachers can modify instruction. Because many of these assessment tools and strategies are formative in nature, the information garnered from their implementation can be used to immediately inform teachers' instructional decisions [6]. The teacher can use information collected during the learning process to evaluate her own teaching and to make changes to future lessons around the needs and goals of those students. As teachers become more aware of their students' interests, needs, strengths, and weaknesses, they are better positioned to modify their instructional strategies and content focus to help maximize student learning.

2. Assess a broader range of skills and abilities to provide a more robust portrait of student ability. Traditional forms of assessment, such as multiplechoice, fill-in-the-blank, and true/false questions privilege memorization and recall skills that demand only a low level of cognitive effort [28, 29]. The assessment tools and strategies outlined in this paper provide more robust means to measure higher-order thinking skills and complex problem-solving abilities [30]. Strategies such as performance-based assessment (PBA) and portfolios take into account multiple measures of achievement and rely on multiple sources of evidence, moving beyond the standardized examinations most commonly used for school accountability [29, 31]. Self- and peer-assessment both teach and assess a broader range of life skills, such as self-reflection, collaboration, and communication. As a tool to measure student learning, rubrics allow teachers to measure multiple dimensions of learning (rather than just content knowledge) and to provide a more detailed assessment of each student's abilities instead of just a number or percent correct.

3. Offer students feedback about their learning and guidance on how they can improve. Giving feedback to students about their current knowledge, abilities, or performance, the desired level of knowledge, abilities, or performance, and the gap between the two is a critical function of formative assessment $[3,32]$ if it is to improve teaching and learning. Effective feedback should collect information about how and what students understand and misunderstand and allow teachers and students to find directions and strategies to improve [3]. The feedback also should help students understand the goals of their learning. This is especially important when we are talking about complex learning outcomes that are not measured by content recall tests [32]. Final course grades, for example, are at such a distance from the day-to-day learning activities that students would not be able to 
identify specific strengths or weaknesses in knowledge or abilities, and that type of grade would not help them reflect on which learning strategies or practices had been most or least beneficial for them.

4. Give students new roles in the assessment process that make assessment a learning experience. In contrast to the traditional teacher-designed, teacheradministered, teacher-graded tests, assessment for learning strategies give students active roles throughout the assessment process. Involving students in the creation of assessment criteria, the diagnosis of their strengths and weaknesses, and the monitoring of their own learning transfers the locus of instruction from the teacher to his or her students [33]. Giving students these new roles fosters metacognition and active participation, and ultimately puts students at the center of the learning process [34]. During peerassessment, students are asked to be the actual evaluator offering feedback and suggestions on how to improve their classmates' work. When created collaboratively, many of these assessments enable teachers and students to interact in a way that blurs the roles in the teaching and learning process [35]. When students are part of the assessment process, they are more likely to take charge of their own learning process and products and will be more likely to want to make improvements on future work [36].

\section{Five effective assessment strategies}

There are many instructional practices and tools that could be classified as assessment for learning, but here we present five broad categories selected because we have either seen them being used in developing countries or we feel they may be effective in those contexts. They also share one common characteristic: All of these strategies can be used with the whole class. They do not require teachers to tailor the assessment for each student, yet the assessment still provides personalized feedback. We felt this was important for teachers with many students. For example, a portfolio assessment will have common criteria for each student, yet each student is able to trace his or her own learning progression over time.

The following sections describe five assessment tools and strategies: (1) rubrics, (2) performance-based assessments (PBAs), (3) portfolios, (4) student selfassessment, and (5) peer-assessment.

\subsection{Rubrics}

Rubrics are both a tool to measure students' knowledge and ability and an assessment strategy. A rubric allows teachers to measure certain skills and abilities not measurable by standardized testing systems that assess discrete knowledge at a fixed moment in time [37]. Rubrics are probably the most widely used assessment for learning practices.

The rubric is not only utilized in conjunction with summative assessments, it is a tool that can enhance the entire learning process from start to finish by serving a number of purposes, including communicating expectations for an assignment and providing focused feedback on a project still in process. The rubric can function as a teaching as well as an assessment tool [38, 39]. Collaborative rubric development also can promote cooperation between teachers and students as they work together to build and utilize the tool [40]. Inviting students to participate in the generation of rubric criteria not only pushes students to think more deeply about their learning, it helps foster a sense of responsibility for their own learning process and helps develop critical thinking skills that can be transferred to other learning situations [38, 40-42]. As such, rubrics encourage self-monitoring and self-assessment, and give structure for a final grade on an end product $[9,38,40]$.

Our own research on the Intel Teach professional development programs, which introduces the use of rubrics, finds that teachers in almost all countries are interested in learning about and using rubrics: On a survey of over 9,000 participants in 16 countries, $57 \%$ of respondents reported increasing their use of rubrics [43]. In our fieldwork in developing countries, we have seen teachers using rubrics to broaden the range of learning dimensions that they assess to target such things as creativity, communication skills, or collaboration. In both Costa Rica and Chile, for example, there even were teachers who had students co-develop dimensions and expectations [44]. However, our literature review found only a few research articles examining the use of rubrics [45].

\subsection{Performance-based assessments}

Performance-based assessments (PBAs), also known as project-based or authentic assessments, are generally used as a summative evaluation strategy to capture not only what students know about a topic but whether they have the skills to apply that knowledge in a real-world situation.

There are many types of products that could be used as part of a PBA. Some examples include: designing and constructing a model; developing, conducting, and reporting on a survey; carrying out a science experiment; writing a letter to the editor of a newspaper; creating and testing a computer program; and outlining, researching, and writing an in-depth report $[46,47]$. Regardless of the type of performance, the common denominator across all PBAs is that students are asked to perform an authentic task that 
simulates a real-life experience and mimics real-world challenges [29, 48].

PBA, coupled with a well-designed measurement tool such as a scoring rubric, can provide how and why a student might be struggling, versus just the what of standardized tests; as a result, PBA actually can help teachers figure out how their students best learn [49, 50]. PBA, used as a formative assessment, also provides more timely feedback than do large-scale standardized tests. Standardized tests can take a number of months to produce results, but PBA allows teachers to make meaningful adjustments while they are still teaching their current students [31, 46]. Additional benefits of PBAs are that they are inherently more student-centered, and are better at assessing higher-order thinking and other 21 st-century skills $[31,47]$.

PBA is another assessment for learning strategy presented in the Intel Teach courses that we have seen widely adopted among participant teachers. On the Intel teacher survey study in $2005,67 \%$ of participants in 16 countries increased their use of PBA [43]. Most of the PBA activities that we observed in various field studies of the Intel programs in developing countries generally consisted of students presenting PowerPoint presentations on research and taking questions from peers, although we have seen students in many countries, such as Argentina, Peru, Turkey, Jordan and India, give presentations to parents and the community $[51,52]$. Again, there is little research on the use of PBA in less-developed countries [53].

\subsection{Portfolio assessment}

The most salient characteristic of the portfolio assessment is that, rather than being a snapshot of a student's knowledge at one point in time (like a single standardized test), it highlights student effort, development, and achievement over a period of time: Portfolios measure a student's ability to apply knowledge rather than simply to regurgitate it. Portfolios are one of the most flexible forms of assessment because they can be effectively adapted across subject areas, grade levels, and administrative contexts (i.e., to report individual student progress, to compare achievement across classrooms or schools, and to increase parent involvement in student learning) $[36,42]$.

Portfolios foster self-reflection and awareness among students, as they often are asked to review previous assignments and projects and to assess strengths and weaknesses of both their processes and their final products [36].

When well-integrated, portfolios also can foster collaboration among students and their peers as well as between students and their teacher [54]. Students' critiques and evaluations of classmates' work can even be included as an additional artifact in the portfolio collection. Nunes [33] believes that one of the underlying principles of portfolio development is that "it should be dialogic and facilitate ongoing interaction between teacher and students."

Technology is playing an increasingly important role in enabling teachers to use portfolios. In the past decade, portfolios have moved from paper folders and file cabinets to electronic databases in social networks embedded within the online "cloud." While eportfolios offer many of the same benefits of conventional portfolios, there are additional advantages that affect learning, teaching, and administration, including increased storage space, easier editing, and more opportunity for creativity.

There is a small body of research from Latin America and the Middle East on portfolios. The research in Latin American is at the university level and found portfolios to be an effective strategy promoting student self-reflection that helped guide students' future learning [55-57]. Mellado Hernández also looked at the use of an online portfolios tool to find that students preferred the online tool to paperbased portfolios. When the portfolio is well-integrated into a teacher's instructional practices, it can function as a strategy to increase student learning across a variety of subject areas. Studies in Iran and in Turkey showed increased student achievement in English as a foreign language [35], science [58], and writing and drawing [54].

\subsection{Self-assessment}

Self-assessment is generally viewed as a formative strategy, rather than being used to determine a student's final grade. The main purpose is for students to identify their own strengths and weaknesses and to work to make improvements to meet specific criteria [59], or for learners to consider and give feedback to other learners about the quality or value of their work [60]. A number of channels can be used to aid students in their self-assessment, including journals, checklists, rubrics, questionnaires, interviews, and student-teacher conferences. As with the previous assessment strategies, the rubric is often the most effective tool to help monitor and measure student self-assessment.

Self-assessment is used to promote self-regulation, to help students reflect on their progress, and to inform revisions and improvements on a project or paper [59, 61]. Ross [62] argues that in order for self-assessment to be truly effective, four conditions must be in place: the self-assessment criteria are negotiated between teachers and students; students are taught how to apply the criteria; students receive feedback on their self- 
assessments; and teachers help students use assessment data to develop an action plan.

An additional strength of self-assessment as a formative assessment tool is that it allows every student to get feedback on his or her work. Few classrooms allow teachers the luxury of regularly responding to each individual student, so when students are trained in self-assessment, it makes them less reliant on teachers to advance their learning [59]. Self-assessment is an interesting strategy to consider in many contexts where there are high student-teacher ratios and short school days, because much of the work can be done by the students and on their own time.

The few studies on self-assessment find it to be a valuable practice. For example, McDonald and Boud [63] report that high-school students in Barbados who were trained in self-assessment not only felt better prepared for their external examinations, they actually outperformed their peers who had not received the training. There are a few other studies on selfassessment in developing-country contexts: Cristancho Garcia [55] looked at portfolios as a self-assessment tool, and Conteh and Moanakwena [64] looked at selfassessment as a critical part of collaborative projects among Botswana university students.

\subsection{Peer-assessment}

Peer-assessment, much like self-assessment, is a formative assessment strategy that gives students a key role in evaluating learning [65]. Peer-assessment approaches can vary greatly, but the primary goal for using peer-assessment is to provide feedback to learners, since student time always will be more plentiful than teacher time; that makes this strategy particularly relevant for developing-country contexts, which often have many students per teacher.

Peer-assessments can be used for a variety of products, such as papers, presentations, projects, or other skilled behaviors. Feedback that students are asked to provide can confirm existing information, identify or correct errors, and offer insight on process, problem solving, or clarity of communication [66].

Peer-assessment is associated with both performance gains and cognitive gains for students who receive feedback and for students as they give feedback. The research suggests that, when done properly, peer-assessment strategies can improve the quality of learning to a degree equivalent to gains from teacher assessment [60]. Giving and receiving feedback impacts metacognitive abilities such as self-regulation $[66,67]$, influencing time on task and engagement in learning, and improving learning outcomes. Asking students to provide feedback to others also can improve their own work as they internalize standards of excellence [68].
When used in conjunction with collaborative learning, peer-assessment also can improve interpersonal skills, such as group work, consensus building, or seeking and providing help [69, 70]. In collaborative peer-assessment techniques, students could work in groups to review work, an entire class might evaluate student presentations, or students can even be asked to assess their own group's work.

Work by Carless [71] and Bryant and Carless [72] explored the reactions to peer-assessment strategies of Chinese students from a "test-dominated" culture, and found that students saw value in peer-assessment as a way to help them prepare for tests. Conteh and Moanakwena [64] researched the use of peer- and selfassessment strategies at a university in Botswana to find that students valued peer feedback on their group projects since the peers knew more than the professor about details of the group project and were able to provide better feedback.

\section{Conclusion}

From 15 years of conducting field work in many developing countries, and reviewing survey data from teachers in over 20 countries, we know that many assessments for learning strategies can work within the contextual challenges that teachers in developing countries often face-large class size, short lesson periods, and limited resources. We have been able to observe the use of assessment-for-learning approaches in classrooms in countries as diverse as India, Turkey, Chile, and Costa Rica [51, 73, 74]. In our fieldwork with teachers trained through the various programs, we have seen assessment practices ranging from studentand teacher-designed rubrics in Chile to performancebased assessments in Turkey and India.

These five assessment tools and strategies overlap not only in the ways in which they can push teaching and learning into the 21st century, but in the types of supports that are needed to make that push successful. While all of the assessment strategies and tools discussed can be developed by a teacher in his or her classroom, in order to maximize the impact on teaching and learning teachers require support beyond the confines of the classroom walls. School administrators, as well as leaders at the local, state, and even national levels, must be prepared to offer various types of supports, including research and development grants, relevant professional development (PD), sufficient planning time, and access to high-quality resources. Moving beyond standardized testing and single-grade assessment is a step in the right direction, but the adoption and integration of classroom-based assessments will be truly successful only if leaders take the vital next steps in ensuring that these necessary supports are in place 
While the focus on reforming national examinations should not be abandoned, we urge ministries, education administrators, researchers, and teachers to broaden their view and support the use of classroom-based assessments. The research from the developed world strongly suggests that these assessment tools and strategies can positively affect a number of key areas of teaching and learning, and yet assessment for learning is not being harnessed to improve education in the lessdeveloped world. To promote assessment for learning in developing countries, there are three critical issues that must be addressed: (1) developing pilot projects that adapt these strategies to the complex contexts of developing countries; (2) researching those projects to better understand what works, what doesn't, and why; and (3) creating a policy context that sufficiently and effectively supports teachers in using innovative, classroom-based assessment-for-learning strategies.

\section{References}

[1] D. H. Kamens, C. L. McNeely, Globalization and the Growth of International Educational Testing and National Assessment. Comparative Education Review 54, 5 (2010).

[2] P. Black, D. Wiliam, Assessment and classroom learning. Assessment in Education: Principles, Policy \& Practice 5, 7 (1998).

[3] J. Hattie, H. Timperley, The Power of Feedback. Review of Educational Research 77, 81 (March 1, 2007, 2007).

[4] W. J. Popham, Transformative Assessment. (ASCD, 2008).

[5] Assessment Reform Group, “Assessment for Learning: 10 Principals" (British Educational Research Association (BERA), London, 2002).

[6] M. Heritage, "Formative Assessment and NextGeneration Assessment Systems: Are We Losing an Opportunity?" (Council of Chief State School Officers, Washington, DC, 2010).

[7] D. Wiliam, paper presented at the Making mathematics vital: Proceedings of the twentieth biennial conference of the Australian Association of Mathematics Teachers, 2007.

[8] H. H. Jacobs, in Curriculum 21: Essential Education for a Changing World, H. H. Jacobs, Ed. (ASCD, Alexandria, VA, 2010).

[9] J. D. Bransford, A. L. Brown, R. R. Cocking, Eds., How People Learn: Brain, Mind, Experience, and School: The Expanded Edition, (National Research Council/ National Academy Press, Washington, DC, 2000).

[10] A. Hume, R. K. Coll, Assessment of Learning, for Learning, and as Learning: New Zealand Case Studies. Assessment in Education: Principles, Policy \& Practice 16, 269 (2009).

[11] Organization for Economic Co-operation and Development, Ed., Formative assessment: Improving learning in secondary classrooms, (OECD, Paris, 2005).

[12] D. Sluijsmans, S. Brand-Gruwel, J. van Merrienboer, R. Martens, Training Teachers in Peer-Assessment Skills:
Effects on Performance and Perceptions. Innovations in Education and Teaching International 41, 59 (2004).

[13] H. Braun, A. Kanjee, E. Bettinger, M. Kremer, Improving Education Through Assessment, Innovation, and Evaluation. (American Academy of Arts and Sciences, Cambridge, MA, 2006).

[14] T. Kellaghan, V. Greaney, paper presented at the Association for the Development of Education in Africa (ADEA) Biennial Meeting, Grand Baie, Mauritius, December 3-6 2003.

[15] P. Ravela, Consignas, devoluciones y calificaciones: los problemas de la evaluación en las aulas de educación primaria en América Latina. Páginas de Educación 2, 49 (2009).

[16] EFA Global Monitoring Report Team, "Education for all: the quality imperative; EFA global monitoring report, 2005" (UNESCO, Paris, 2004).

[17] P.-K. Fok, K. Kennedy, K.-s. J. Chan, W.-m. F. Yu, paper presented at the 32nd Annual Conference of the International Association for Education Assessment, Singapore, May 21-26 2006.

[18] R. Tsuneyoshi, The New Japanese Educational Reforms and the Achievement "Crisis" Debate. Educational Policy 18, 364 (May, 2004).

[19] H. Valdés Veloz, E. Treviño, M. Castro, R. Costilla, C. G. Acevedo, Eds., Reporte Técnico del Segundo Estudio Regional Comparativo y Explicativo (SERCE): los aprendizajes de los estudiantes de América Latina y el Caribe, (OREALC/UNESCO Santiago, Santiago, 2009), pp. 585.

[20] E. Schiefelbein, P. Schiefelbein, From Screening to Improving Quality: the case of Latin America. Assessment in Education: Principles, Policy \& Practice 10, 141 (2003).

[21] L. Chisholm, "The Quality of primary education in South Africa; Background paper for the Education for all global monitoring report 2005: the quality imperative; 2004" (UNESCO, Paris, 2004).

[22] H. J. Nenty, O. O. Adedoyin, J. N. Odili, T. E. Major, Primary Teacher's Perceptions of Classroom Assessment Practices as Means of Providing Quality Primary/Basic Education by Botswana and Nigeria. Educational Research and Reviews 2, 074 (2007).

[23] P. C. Otiato Ojiambo, Quality of Education as a Tool for Development: A Case Study of Kenya's Educational Reforms. The African Symposium: An On Line Journal Of African Educational Research Network 8, 102 (2008).

[24] M. Prieto, G. Contreras, Las concepciones que orientan las practicas evaluativas de los profesores: un problema a develar. Estudios pedag Ûgicos (Valdivia) 34, 245 (2008).

[25] J. L. Saldanha, S. L. Talim, Avaliação da Aprendizagem na Escola Plural: $O$ que Ocorre na Prática? Revista Electrónica Iberoamericana sobre Calidad, Eficacia y Cambio en Educación 52, 84 (2007).

[26] S. Vandeyar, R. Killen, Educators' conceptions and practice of classroom assessment in post-apartheid South Africa. South African Journal of Education 27, (2007).

[27] M. Zamora Hernández, T. Moreno Olivos, Para muestra un botón: la evaluación en las aulas de secundaria. Revista del Centro de Investigación. Universidad La Salle, 8, 99 (July-December, 2009). 
[28] S. Dikli, Assessment at a distance: Traditional vs. Alternative Assessments. The Turkish Online Journal of Educational Technology 2, (July, 2003).

[29] L. A. Shepard et al., "Effects of Introducing Classroom Performance Assessments on Student Learning" (National Center for Research on Evaluation, Standards and Student Testing, University of Colorado at Boulder, Boulder, CO, 1995).

[30] T. Palm, in Practical Assessment, Research \& Evaluation. (2008), vol. 13.

[31] G. H. Wood, L. Darling-Hammond, M. Neill, P. Roschewski. (Forum for Education and Democracy, Washington, D.C., 2007).

[32] D. R. Sadler, Formative Assessment and the Design of Instructional Systems. Instructional Science 18, 119 (1989).

[33] A. Nunes, Portfolios in the EFL classroom: disclosing an informed practice. English Language Teachers Journal 58, (2004).

[34] J. H. McMillan, J. Hearn, Student Self-Assessment: The Key to Stronger Student Motivation and Higher Achievement. Educational Horizons 87, 40 (2008).

[35] N. Barootchi, M. H. Keshavarz, Assessment of achievement through portfolios and teacher-made tests. Educational Researcher 44, 279 (2002).

[36] D. Sweet, O. o. E. R. a. I. (OERI), Ed. (Office of Educational Research and Improvement (OERI), Washington, D.C., 1993).

[37] S. Reeves, B. Stanford, Rubrics for the Classroom: Assessments for Students and Teachers. The Delta Kappa Gamma Bulletin Fall, 24 (2009).

[38] H. L. Andrade, D. Ying, W. Xiaolei, Putting Rubrics to the Test: The Effect of a Model, Criteria Generation, and Rubric-Referenced Self-Assessment on Elementary School Students' Writing. Educational Measurement: Issues \& Practice 27, 3 (2008).

[39] J. W. Popham, What's Wrong-and What's Right- WIth Rubrics. Educational Leadership October, 72 (1997).

[40] E. Lee, S. Lee, Effects of Instructional Rubrics on Class Engagement Behaviors and the Achievement of Lesson Objectives by Students with Mild Mental Retardation and Their Typical Peers. Education and Training in Developmental Disabilities 44, 396 (2009).

[41] M. J. Skillings, R. Ferrell, Student-generated rubrics: Bringing students into the assessment process. The Reading Teacher 53, 452 (2000).

[42] National Research Council, "Scientific Research in Education" (National Academy Press, Washington DC, 2002).

[43] D. Light, K. McMillan Culp, R. Menon, S. Shulman, "Intel ${ }^{\circledR}$ Teach to the Future Essentials Course: Impact Survey Results for 2005" (EDC/Center for Children and Technology, New York, 2006).

[44] D. Light, The Role of ICT in Enhancing Education in Developing Countries: Findings from an Evaluation of The Intel Teach Essentials Course in India, Turkey, and Chile. Journal of Education for International Development 4, 1 (December, 2009).

[45] Á. H. Flores Samaniego, A. Gómez Reyes, Aprender Matemática, Haciendo Matemática: la evaluación en el aula. . Educación Matemática 21, 117 (2009).

[46] L. Darling-Hammond, R. Pecheone, in Meaningful Measurement: The Role of Assessments in Improving
High School Education in the Twenty-First Century, L. M. Pinkus, Ed. (Alliance for Excellent Education, Washington, DC, 2009).

[47] D. G. Wren, "Performance Assessment: A key component of balanced assessment system" (Virginia Beach City Public Schools, Department of Research, Evaluation, and Assessment, Virginia Beach, 2009).

[48] G. P. Wiggins, J. McTighe, Understanding by design. (Association for Supervision and Curriculum Development, Alexandria, VA, ed. Expanded 2nd, 2005), pp. xi, 370 p.

[49] B. Falk, S. W. Ort, K. Moirs, Keeping the Focuson the Child: Supporting and Reporting on Teaching and Learning With a Classroom-Based Performance Assessment System. Educational Assessment 12, 47 (2007).

[50] L. A. Shepard, Commentary: Evaluating the Validity of Formative and Interim Assessment. Educational Measurement: Issues and Practice 28, 32 (2009).

[51] D. Light, D. K. Polin, S. Strother, "Emerging Changes in ICT-rich Learning Environments: The role of the Intel ${ }^{\circledR}$ Teach Essentials Course in Changing Teacher Practice in Three Countries." (EDC/Center for Children and Technology, 2009).

[52] D. Light, C. Rockman, in Evaluation of the Jordan Education Initiative. (Education Development Center, Washington, D.C., 2008), pp. 57.

[53] M. A. Segura Castillo, La evaluación de los aprendizajes basada en el desempeño por competencias. Actualidades Investigativas en Educación 9, 1 (2009).

[54] E. Tezci, A. Dikici, The Effects of Digital Portfolio Assessment Process on Students' Writing and Drawing Performances. The Turkish Online Journal of Educational Technology 5, 46 (2006).

[55] A. M. Cristancho García, La evaluación por portafolio: estrategia para modelar la responsabilidad personal. Un ejercicio de reflexión autocrítica sobre el papel de la mediación. Psicología desde el Caribe [en línea] (enerojunio, 2003).

[56] G. Farías Martínez, M. Ramírez Montoya, Desarrollo de cualidades reflexivas de profesores en formación inicial a través de portafolios electrónicos. Revista Mexicana de Investigación Educativa 15, 141 (2010).

[57] M. Mellado Hernández, Portafolio en línea en la formación inicial docente. REDIE. Revista Electrónica de Investigación Educativa 12, 1 (2010).

[58] M. Çakan, G. Mihladiz, B. Göçmen-Taskin, How Portfolios Use Affects Students' Learning and Their Attitudes toward 6th Grade Science Lesson. International Online Journal of Education Sciences 2, 362 (2010).

[59] H. Andrade, A. Valtcheva, Promoting Learning and Achievement through Self-Assessment. Theory Into Practice 48, 12 (2009).

[60] K. J. Topping, Peer Assessment. Theory Into Practice 48, 20 (2009)

[61] J. A. Ross, in Practical Assessment, Research \& Evaluation. (2006), vol. 11, pp. 1.

[62] J. A. Ross, C. D. Bruce, Student achievement effects of technology-supported remediation of understanding of fractions. International Journal of Mathematical Education in Science \& Technology 40, 713 (2009). 
[63] B. McDonald, D. Boud, The Impact of Self-assessment on Achievement: the effects of self-assessment training on performance in external examinations. Assessment in Education 10, 209 (2003).

[64] B. G. Conteh, P. G. Moanakwena, paper presented at the Eduvate 2008 Conference, South Africa, 25 - 27 June 2008.

[65] K. J. Topping, Trends in Peer Learning. Educational Psychology 25, 631 (2005).

[66] D. L. Butler, P. H. Winne, Feedback and Self-Regulated Learning: A Theoretical Synthesis. Review of Educational Research 65, 245 (1995).

[67] A. W. Bangert, An Exploratory Study if the Effects of Peer Assessment Activities on Student Motivational Variables that Impact Learning. Journal of Student Centered Learning 1n2, 69 (2003).

[68] L. Li, X. Liu, A. L. Steckelberg, Assessor or Assessee: How Student Learning Improves by Giving and Receiving Peer Feedback. British Journal of Educational Technology 41, 525 (2010).

[69] C. C. Brown, K. J. Topping, C. Henington, C. H. Skinner, Peer monitoring of learning behaviour: The case of 'Checking Chums'. Educational Psychology in Practice 15, 174 (1999).

[70] J. A. Ross, Effects of feedback on student behavior in cooperative learning. Elementary School Journal 96, 125 (1995).

[71] D. Carless, Prospects for the Implementation of Assessment for Learning. Assessment in Education Principles Policy and Practice 12, 39 (2005).

[72] D. A. Bryant, D. R. Carless, Peer Assessment in a TestDominated Setting: Empowering, Boring or Facilitating Examination Preparation? Educational Research for Policy and Practice 9, 3 (2010).

[73] A. T. León Sáenz, M. Castro, D. Light, "Costa Rica Case Study Report" (EDC/Center for Children and Technology, New York, 2008).

[74] D. Light, C. Mora, M. Brenes Monge, "Formative Evaluation of the Costa Rican Pilot of the Intel ${ }^{\circledR}$ Teach to the Future Workshop on Teaching Thinking with Technology" (EDC/CCT, New York, 2005). 